\title{
Direct Electrochemical Synthesis of Aluminium(III) Thiolates and their Coordination Compounds
}

\author{
BALJIT SINGH*, KANCHAN BALA, SUKHVEER SINGH and KISHANPAL SINGH \\ Department of Chemistry, Punjabi University, Patiala-147002, Punjab, India \\ baljit_chemz@yahoo.co.in
}

Received 31 January 2013 / Accepted 16 February 2013

\begin{abstract}
Electrochemical oxidation of a sacrificial aluminum anode with thiols (RSH) like ethanethiol, 2-propanethiol, 1-butanethiol, 2-methyl-2-propanethiol, 1-pentanethiol and thiophenol in the presence of tetrabutylammonium chloride as a conductive additive, acetonitrile as a solvent and platinum as a cathode yield aluminium(III) thiolates. Adducts of these compounds with ligand $\mathrm{L}$ $(\mathrm{L}=1,10$ phenanthroline and 2,2'-bipyridyl) have also been obtained by addition of these ligands to the electrolysis phase. These electrochemically synthesized products have been characterized by microanalysis, physical measurements and IR spectral studies. These have been identified as $\mathrm{Al}(\mathrm{SR})_{3}$ and $\mathrm{Al}(\mathrm{SR})_{3}$.L. All these products are associated with very high current efficiencies.
\end{abstract}

Keywords: Electrochemical reactions, Sacrificial electrode, Aluminium(III) thiolates

\section{Introduction}

Direct electrochemical synthesis of metal thiolates by anodic dissolution of metals in thiols, in the presence of a conductive additive seems a very promising method. In the world today, this technique has become progressively dominant and attracted a great deal of attention because of their synthetic utility in organic ${ }^{1-2}$, inorganic ${ }^{3}$, green, nanochemistry ${ }^{4}$, metal deposition, chemical and pharmaceutical industries ${ }^{5}$, neurosciences etc. Metal sulphur complexes have become the subject of great interest because of their importance in material precursors, metalloenzymes and catalyts ${ }^{6}$.

In continuation and growing interest of our laboratory in electrochemistry, we have been doing research since the last two decades on this fascinating technique for the preparation of different inorganic and organometallic compounds by using different metals like mercury, cadmium, zinc, antimony, copper, bismuth and aluminium as a sacrificial electrode $^{7-13}$. We, here in, wish to report the synthesis of aluminium(III) thiolates and their coordination compounds with ligand 1,10-phenanthroline and 2,2'-bipyridyl. This technique is simple, high yielding, efficient, one step and as being environmentally favourable ${ }^{14}$.

\section{Experimental}

Acetonitrile was kept over 4A molecular sieves for 24 hours and then double distilled. Freshly distilled acetonitrile was used as a solvent in all these reactions. Tetrabutylammonium 
chloride (Acros) was crystallized from conductivity water and dried under reduced pressure at $100{ }^{\circ} \mathrm{C}$. It was then used as a supporting electrolyte in these reactions. Electrolysis has been carried out in a $H$-type cell, made of pyrex glass in which the cathode and anode compartments were separated from each other by a sintered glass disc of G-3 porosity. Aluminium electrode $\left(2 \times 10 \times 0.2 \mathrm{~cm}^{3}\right)$ and platinum foil $\left(1.0 \times 1.0 \mathrm{~cm}^{2}\right)$ was used as anode and cathode respectively. Both compartments were provided with two openings; One for guard tube and other for electrode. Direct current was obtained with the help of Toshniwal electrophoresis power supply. The electrolytic solution was stirred efficiently using magnetic stirrer.

\section{Procedure}

$3 \mathrm{~mL}$ of thiol, $1.0 \mathrm{~g}$ of tetrabutylammonium chloride and $150 \mathrm{~mL}$ of freshly distilled acetonitrile were taken in $H$-type cell. Aluminium electrode was dipped in the anode compartment and platinum foil in the cathode compartment and outlets were sealed after fitting the guard tubes. Necessary connections were made with the power supply and potential across the electrode was then adjusted so that a current of $20 \mathrm{~mA}$ passed through the solution. The cell may be represented as:

$$
\begin{array}{l|l|l}
\mathrm{Al}_{(+)} & \mathrm{RSH}+\mathrm{Bu}_{4} \mathrm{NCl}+\mathrm{CH}_{3} \mathrm{CN} \mathrm{Pt}\left(\mathrm{Al}_{(-)}\right. & \mathrm{Al}_{(+)}
\end{array}
$$

Where $\mathrm{Al}_{(+)}$is aluminium anode, $\mathrm{Pt}_{(-)}$is platinum cathode, $\mathrm{Bu}_{4} \mathrm{NCl}$ is tetrabutyl ammonium chloride (supporting electrolyte), RSH is thiol used in the system.

After conducting electrolysis for 10 hours, the solid product separated in the anode compartment was filtered, washed with hot acetonitrile, dry ether and finally dried under vacuum. All efforts were made to protect the products from air and moisture.

The coordination compounds of these products have also been synthesized by adding $1.0 \mathrm{~g}$ of ligand (1,10-phenanthroline or 2,2'-bipyridyl) to the above substrates before starting the electrolysis. The other details are same as discussed above.

Accurately weighed amount of the product $(100 \mathrm{mg})$ was heated to dryness four times with $3.0 \mathrm{~mL}$ of concentrated nitric acid and diluted to $100 \mathrm{~mL}$ with distilled water. Using this solution, aluminium contents in the products were estimated by oxine method ${ }^{15}$.

Melting point of all these compounds was determined using electrical device with a heating rate of $5{ }^{\circ} \mathrm{C}$ per minute. Carbon, hydrogen, sulphur and nitrogen (where applicable) contents in the products were determined through 'Elementor Vario EL'.

\section{CHNS elemental analyzer}

Infra red spectra of the products have been recorded on Perkin- Elmer spectrophotometer (FTIR) in the region of $4000-400 \mathrm{~cm}^{-1}$ using $\mathrm{KBr}$ pallets. The current efficiencies ${ }^{16}$ (gram equivalents of metal dissolved per faraday of electricity passed) of all these reactions were determined using Faraday's first law of electrolysis by electrolyzing the above system under similar conditions but for exactly two hours at a constant current of $20 \mathrm{~mA}$. The solution in the anode compartment was taken out. The anode compartment of the cell was washed three times with acetonitrile. The solution of the anode compartment along with its washings was distilled in rotary film evaporator till $10 \mathrm{~mL}$ of content was left in the flask. The contents were then transferred to a beaker and heated to dryness. Aluminium contents were then determined in the dry mass as discussed above. The ratio of experimental and theoretical aluminium contents give the current efficiency of the system. 


\section{Results and Discussion}

\section{Aluminium(III) thiolates}

Electrochemical reactions of thiols at sacrificial aluminium anode and inert platinum cathode yield aluminium (III) thiolates. The mechanism of the reaction is given in Scheme 1 .

At inert platinum cathode: $6 \mathrm{RSH}+6 \mathrm{e}^{-} \longrightarrow 6 \mathrm{RS}^{-}+3 \mathrm{H}_{2}$

At sacrificial aluminium anode: $6 \mathrm{RS}^{-}+2 \mathrm{Al}$ $2 \mathrm{Al}(\mathrm{SR})_{3}+6 \mathrm{e}^{-}$

\section{Scheme 1}

The electrolysis has been conducted (10 hours) so that sufficient amount of the product may be produced. Solvent and supporting electrolyte remain unaffected as long as highly electroactive species (thiol and aluminium in these systems) are present in the solution. The electrolysis characteristics of all the systems are recorded in Table 1.

Table 1. Electrolysis characteristics, analytical and other related data of electrolytic products of thiol at aluminium anode (Potential: $50 \mathrm{~V}$, Current in Coulombs: 720)

\begin{tabular}{|c|c|c|c|c|c|c|c|c|}
\hline \multirow[t]{2}{*}{ System } & \multirow{2}{*}{ 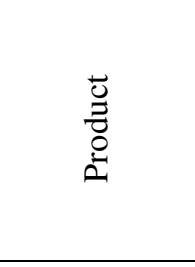 } & \multirow{2}{*}{$\frac{\overline{0}}{0}$} & \multicolumn{5}{|c|}{$\begin{array}{l}\text { Elemental analysis\% } \\
\text { found(calculated) }\end{array}$} & \multirow{2}{*}{ 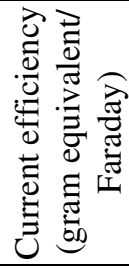 } \\
\hline & & & $\mathrm{Al}$ & $\mathrm{C}$ & $\mathrm{H}$ & $S$ & $\mathrm{~N}$ & \\
\hline Ethanethiol & $\mathrm{Al}\left(\mathrm{SC}_{2} \mathrm{H}_{5}\right)_{3}$ & Grey & $\begin{array}{c}12.6 \\
(12.8)\end{array}$ & $\begin{array}{c}34.0 \\
(34.3)\end{array}$ & $\begin{array}{c}7.0 \\
(7.1)\end{array}$ & $\begin{array}{c}45.2 \\
(45.7)\end{array}$ & --- & 0.80 \\
\hline 2-Propanethiol & $\mathrm{Al}\left(\mathrm{SC}_{3} \mathrm{H}_{7}\right)_{3}$ & Grey & $\begin{array}{c}10.4 \\
(10.7)\end{array}$ & $\begin{array}{c}42.2 \\
(42.8)\end{array}$ & $\begin{array}{c}8.1 \\
(8.3)\end{array}$ & $\begin{array}{c}37.6 \\
(38.1)\end{array}$ & --- & 0.78 \\
\hline 1-Butanethiol & $\mathrm{Al}\left(\mathrm{SC}_{4} \mathrm{H}_{9}\right)_{3}$ & Grey & $\begin{array}{c}9.0 \\
(9.2)\end{array}$ & $\begin{array}{c}48.7 \\
(48.9)\end{array}$ & $\begin{array}{c}8.9 \\
(9.2)\end{array}$ & $\begin{array}{c}32.4 \\
(32.6)\end{array}$ & --- & 0.81 \\
\hline $\begin{array}{l}\text { 2-Methyl-2- } \\
\text { propanethiol }\end{array}$ & $\mathrm{Al}\left(\mathrm{SC}_{4} \mathrm{H}_{9}\right)_{3}$ & Grey & $\begin{array}{c}9.1 \\
(9.2)\end{array}$ & $\begin{array}{c}48.5 \\
(48.9)\end{array}$ & $\begin{array}{c}9.0 \\
(9.2)\end{array}$ & $\begin{array}{c}32.3 \\
(32.6)\end{array}$ & --- & 0.84 \\
\hline 1-Pentanethiol & $\mathrm{Al}\left(\mathrm{SC}_{5} \mathrm{H}_{11}\right)_{3}$ & Grey & $\begin{array}{c}7.8 \\
(8.0)\end{array}$ & $\begin{array}{c}53.2 \\
(53.6)\end{array}$ & $\begin{array}{c}9.3 \\
(9.8)\end{array}$ & $\begin{array}{c}28.3 \\
(28.6)\end{array}$ & --- & 0.95 \\
\hline Thiophenol & $\mathrm{Al}\left(\mathrm{SC}_{6} \mathrm{H}_{5}\right)_{3}$ & Grey & $\begin{array}{c}7.4 \\
(7.6)\end{array}$ & $\begin{array}{c}60.8 \\
(61.0)\end{array}$ & $\begin{array}{c}4.0 \\
(4.2)\end{array}$ & $\begin{array}{l}27.0 \\
(27.1)\end{array}$ & --- & 0.82 \\
\hline $\begin{array}{c}\text { Ethanethiol + } \\
\text { 1,10-phenanthroline }\end{array}$ & $\begin{array}{c}\mathrm{Al}\left(\mathrm{SC}_{2} \mathrm{H}_{5}\right)_{3} \\
\mathrm{C}_{12} \mathrm{H}_{8} \mathrm{~N}_{2}\end{array}$ & $\begin{array}{l}\text { Light } \\
\text { Pink }\end{array}$ & $\begin{array}{c}6.5 \\
(6.9)\end{array}$ & $\begin{array}{c}55.0 \\
(55.4)\end{array}$ & $\begin{array}{c}5.5 \\
(5.9)\end{array}$ & $\begin{array}{c}24.1 \\
(24.6)\end{array}$ & $\begin{array}{c}7.0 \\
(7.2)\end{array}$ & 0.85 \\
\hline $\begin{array}{l}\text { 2-Propanethiol }+ \\
\text { 1,10-phenanthroline }\end{array}$ & $\begin{array}{c}\mathrm{Al}\left(\mathrm{SC}_{3} \mathrm{H}_{7}\right)_{3} \\
\mathrm{C}_{12} \mathrm{H}_{8} \mathrm{~N}_{2}\end{array}$ & $\begin{array}{l}\text { Light } \\
\text { Pink }\end{array}$ & $\begin{array}{l}6.0 \\
(6.3)\end{array}$ & $\begin{array}{c}58.0 \\
(58.3)\end{array}$ & $\begin{array}{c}6.1 \\
(6.7)\end{array}$ & $\begin{array}{c}22.0 \\
(22.2)\end{array}$ & $\begin{array}{l}6.3 \\
(6.5)\end{array}$ & 0.97 \\
\hline $\begin{array}{l}\text { 1-Butanethiol + } \\
\text { 1,10-phenanthroline }\end{array}$ & $\begin{array}{c}\mathrm{Al}\left(\mathrm{SC}_{4} \mathrm{H}_{9}\right)_{3} \\
\mathrm{C}_{12} \mathrm{H}_{8} \mathrm{~N}_{2}\end{array}$ & $\begin{array}{l}\text { Light } \\
\text { Pink }\end{array}$ & $\begin{array}{c}5.5 \\
(5.7)\end{array}$ & $\begin{array}{c}60.1 \\
(60.7)\end{array}$ & $\begin{array}{c}7.2 \\
(7.4)\end{array}$ & $\begin{array}{c}20.2 \\
(20.2)\end{array}$ & $\begin{array}{l}5.6 \\
(5.9)\end{array}$ & 0.88 \\
\hline $\begin{array}{c}\text { 2-Methyl-2- } \\
\text { propanethiol + } \\
\text { 1,10-phenanthroline }\end{array}$ & $\begin{array}{c}\mathrm{Al}\left(\mathrm{SC}_{4} \mathrm{H}_{\mathbf{9}}\right)_{3} \\
\mathrm{C}_{12} \mathrm{H}_{8} \mathrm{~N}_{2}\end{array}$ & $\begin{array}{l}\text { Light } \\
\text { Pink }\end{array}$ & $\begin{array}{c}5.6 \\
(5.7)\end{array}$ & $\begin{array}{c}60.6 \\
(60.7)\end{array}$ & $\begin{array}{c}7.0 \\
(7.4)\end{array}$ & $\begin{array}{l}20.0 \\
(20.2)\end{array}$ & $\begin{array}{c}5.7 \\
(5.9)\end{array}$ & 0.94 \\
\hline $\begin{array}{l}\text { 1-Pentanethiol + } \\
\text { 1,10-phenanthroline } \\
\text { Thiophenol + } \\
\text { 1,10-phenanthroline }\end{array}$ & $\begin{array}{c}\mathrm{Al}\left(\mathrm{SC}_{5} \mathrm{H}_{11}\right)_{3} \\
\mathrm{C}_{12} \mathrm{H}_{8} \mathrm{~N}_{2} \\
\mathrm{Al}\left(\mathrm{SC}_{6} \mathrm{H}_{5}\right)_{3} \\
\mathrm{C}_{12} \mathrm{H}_{8} \mathrm{~N}_{2} \\
\end{array}$ & $\begin{array}{l}\text { Light } \\
\text { Pink } \\
\text { Light } \\
\text { Pink } \\
\end{array}$ & $\begin{array}{c}5.0 \\
(5.2) \\
4.8 \\
(5.0) \\
\end{array}$ & $\begin{array}{c}62.5 \\
(62.8) \\
67.1 \\
(67.4) \\
\end{array}$ & $\begin{array}{c}7.8 \\
(7.9) \\
4.2 \\
(4.3) \\
\end{array}$ & $\begin{array}{c}18.4 \\
(18.6) \\
17.7 \\
(17.9) \\
\end{array}$ & $\begin{array}{c}5.4 \\
(5.4) \\
5.0 \\
(5.2) \\
\end{array}$ & 0.80 \\
\hline
\end{tabular}




\begin{tabular}{|c|c|c|c|c|c|c|c|c|}
\hline $\begin{array}{l}\text { Ethanethiol + } \\
\text { 2.2'-bipyridyl }\end{array}$ & $\begin{array}{c}\mathrm{Al}\left(\mathrm{SC}_{2} \mathrm{H}_{5}\right)_{3} \\
\mathrm{C}_{10} \mathrm{H}_{8} \mathrm{~N}_{2}\end{array}$ & $\begin{array}{l}\text { Light } \\
\text { Grey }\end{array}$ & $\begin{array}{c}7.3 \\
(7.4)\end{array}$ & $\begin{array}{c}52.0 \\
(52.4)\end{array}$ & $\begin{array}{c}6.0 \\
(6.3)\end{array}$ & $\begin{array}{c}26.1 \\
(26.2)\end{array}$ & $\begin{array}{c}7.3 \\
(7.6)\end{array}$ & 0.88 \\
\hline 2-propanethiol + & $\mathrm{Al}\left(\mathrm{SC}_{3} \mathrm{H}_{7}\right)_{3}$ & Dark & 6.4 & 55.1 & 7.0 & 23.2 & 6.4 & \\
\hline 2,2'-bipyridyl & $\mathrm{C}_{10} \mathrm{H}_{8} \mathrm{~N}_{2}$ & Pink & $(6.6)$ & $(55.9)$ & (7.1) & $(23.5)$ & $(6.9)$ & 0.77 \\
\hline $\begin{array}{l}\text { 1-Butanethiol + } \\
\text { 2,2'-bipyridyl }\end{array}$ & $\begin{array}{c}\mathrm{Al}\left(\mathrm{SC}_{4} \mathrm{H}_{9}\right)_{3} \\
\mathrm{C}_{10} \mathrm{H}_{8} \mathrm{~N}_{2}\end{array}$ & $\begin{array}{l}\text { Light } \\
\text { Pink }\end{array}$ & $\begin{array}{l}5.9 \\
(6.0)\end{array}$ & $\begin{array}{c}58.1 \\
(58.7)\end{array}$ & $\begin{array}{c}7.2 \\
(7.8)\end{array}$ & $\begin{array}{l}21.0 \\
(21.3)\end{array}$ & $\begin{array}{l}6.0 \\
(6.2)\end{array}$ & 0.85 \\
\hline $\begin{array}{l}\text { 2-Methyl-2- } \\
\text { propanethiol + } \\
2,2^{\prime} \text {-bipyridyl }\end{array}$ & $\begin{array}{c}\mathrm{Al}\left(\mathrm{SC}_{4} \mathrm{H}_{9}\right)_{3} \\
\mathrm{C}_{10} \mathrm{H}_{8} \mathrm{~N}_{2}\end{array}$ & Grey & $\begin{array}{l}5.7 \\
(6.0)\end{array}$ & $\begin{array}{c}58.1 \\
(58.6)\end{array}$ & $\begin{array}{c}7.5 \\
(7.8)\end{array}$ & $\begin{array}{l}21.0 \\
(21.3)\end{array}$ & $\begin{array}{c}6.0 \\
(6.2)\end{array}$ & 0.90 \\
\hline $\begin{array}{c}\text { 1- Pentanethiol + } \\
\text { 2,2'-bipyridyl }\end{array}$ & $\begin{array}{c}\mathrm{Al}\left(\mathrm{SC}_{5} \mathrm{H}_{11}\right) \\
{ }_{3} \mathrm{C}_{10} \mathrm{H}_{8} \mathrm{~N}_{2}\end{array}$ & Grey & $\begin{array}{c}5.3 \\
(5.5)\end{array}$ & $\begin{array}{l}60.6 \\
(60.9)\end{array}$ & $\begin{array}{c}8.2 \\
(8.3)\end{array}$ & $\begin{array}{l}19.3 \\
(19.5)\end{array}$ & $\begin{array}{l}5.5 \\
(5.7)\end{array}$ & 0.82 \\
\hline $\begin{array}{l}\text { Thiophenol + } \\
\text { 2,2'-bipyridyl }\end{array}$ & $\begin{array}{c}\mathrm{Al}\left(\mathrm{SC}_{6} \mathrm{H}_{5}\right)_{3} \\
\mathrm{C}_{10} \mathrm{H}_{8} \mathrm{~N}_{2}\end{array}$ & Pink & $\begin{array}{l}5.0 \\
(5.3)\end{array}$ & $\begin{array}{c}65.4 \\
(65.9) \\
\end{array}$ & $\begin{array}{c}4.4 \\
(4.5) \\
\end{array}$ & $\begin{array}{c}18.6 \\
(18.8)\end{array}$ & $\begin{array}{r}5.4 \\
(5.5) \\
\end{array}$ & 0.76 \\
\hline
\end{tabular}

It has been observed that the electrochemical products are quite stable and are not much affected by air. All these compounds are insoluble in various commonly used organic solvents like chloroform, carbon tetrachloride, benzene, $N, N^{\prime}$-dimethyl formamide, methanol, acetone and pyridine. These products don't melt upto $300{ }^{\circ} \mathrm{C}$ but decompose at a temperature in the range between 200 to $230{ }^{\circ} \mathrm{C}$. The decomposition of products is indicated from the change in colour of these compounds.

Aluminium contents (determined by oxine method) ${ }^{15}$ in these compounds correspond to 3:1 stiochoimetry of thiol and aluminium. Microanalysis for carbon, sulphur and hydrogen and all the analytical data conform to the molecular formula $\mathrm{Al}(\mathrm{SR})_{3}$. The relevant data are summarized in Table 1.

Infrared spectra of these products show that there is no absorption bands corresponding to thiol group i.e in the region of $2600-2499 \mathrm{~cm}^{-1}$ which shows that the product is completely free from thiol. Characteristic bands appeared in the region of $462-400 \mathrm{~cm}^{-1}$ and $1088-970 \mathrm{~cm}^{-1}$. Survey of literature reveals ${ }^{17-19}$ that $v(\mathrm{M}-\mathrm{S})$ and $v(\mathrm{C}-\mathrm{S}) \mathrm{M}$ stretching vibrations appear in the region of $600-400 \mathrm{~cm}^{-1}$ and $1160-900 \mathrm{~cm}^{-1}$. Thus in the present products, bands appeared in the region of $462-400 \mathrm{~cm}^{-1}$ may be assigned to $v(\mathrm{Al}-\mathrm{S})$ stretching vibrations. Presence of these bands and absence of bands due to thiol group in the electrochemical products indicate that the hydrogen of the thiol has been replaced by anodic aluminium.

Review of literature also reveals ${ }^{17-19}$ that the absorption bands due to $v(\mathrm{C}-\mathrm{S}) \mathrm{M}$ stretching vibrations in various metal thiolates exist as bridged and terminal SR groups, an analogy to metal alkoxides ${ }^{20}$. In general, terminal $v(\mathrm{SR})$ groups show absorption bands in the region of $1100-1000 \mathrm{~cm}^{-1}$ and bridged $v(\mathrm{SR})$ groups in the region of $1000-900 \mathrm{~cm}^{-1}$. Infrared spectra of the present electrochemical products show the appearance of two/ three broad bands in the region of $1000-970 \mathrm{~cm}^{-1}$ can be attributed to bridged SR groups thereby showing their polymeric nature which is also supported by high melting point and insoluble nature of these compounds in various organic solvents. The appearance of absorption bands in the region of $1088-1010 \mathrm{~cm}^{-1}$ are assigned to the terminal $v(\mathrm{C}-\mathrm{S}) \mathrm{Al}$. The plausible structure of these metal thiolates is given in Scheme 2.

Infra red spectra of these compounds also reveals that the bands appeared due to bridged thiolates groups are strong as compared to terminal $v(\mathrm{C}-\mathrm{S}) \mathrm{Al}$ stretching vibrations. As the size of the alkyl group in thiol increases the relative intensity of the bands due to bridged thiolate groups decreases indicating that degree of polymerization decreases. In case of thiophenol aluminium complex additional bands around $1600 \mathrm{~cm}^{-1}$ are also observed due to $v$ (C---C) aromatic ring vibrations ${ }^{17}$. 


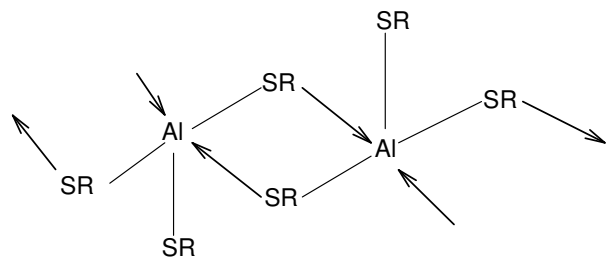

\section{Scheme 2}

Thus, analytical and IR data show that aluminium(III) thiolates conforming to general formula, $\mathrm{Al}(\mathrm{SR})_{3}$, have been synthesized electrochemically.

\section{Coordination compounds of aluminium thiolates}

The aluminium(III) thiolates prepared have been refluxed with 1,10-phenanthroline and 2,2'-bipyridyl separately in polar and non-polar solvents like methanol, ethanol, benzene and acetonitrile for 48 hours in order to prepare coordination compounds of these thiolates. However, analytical and infrared spectral data of these products show that the ligand molecule could not rupture the sulphur bridges in these aluminium(III) thiolates. It may be due to the reason that the metal in these thiolates has already achieved the favourable coordination number through sulphur bridging therefore, further expansion of coordination sphere due to addition of ligand could not be achieved. It was, therefore, thought that the ligand may be added to these thiolates before these form sulphur bridges and get polymerized. Therefore in addition to thiol (RSH) and supporting electrolyte, $1.0 \mathrm{~g}$ of ligand was also added to these systems and then solution was electrolyzed at aluminium anode and inert platinum cathode for 10 hours. The reaction scheme for this is given in Scheme 3.

At Inert Platinum cathode: $6 \mathrm{RSH}+6 \mathrm{e}^{-} \longrightarrow 6 \mathrm{RS}^{-}+3 \mathrm{H}_{2}$

At Sacrificial Aluminium anode: $6 \mathrm{RS}^{-}+2 \mathrm{Al}_{(+)}+2 \mathrm{~L} \longrightarrow 2 \mathrm{Al}(\mathrm{SR})_{3} \mathrm{~L}+6 \mathrm{e}^{-}$

\section{Scheme 3}

The analytical data (Aluminium, carbon, hydrogen, sulphur and nitrogen) in all the products show that ligand molecule has been added and conform to general molecular formula, $\mathrm{Al}(\mathrm{SR})_{3} . \mathrm{L}$. All the relevant data are summarized in Table 1.

Infrared spectra of these coordination compounds show $v(\mathrm{Al}-\mathrm{S})$ and $v(\mathrm{C}-\mathrm{S}) \mathrm{Al}$ modes in the region of $465-429 \mathrm{~cm}^{-1}$ and $1100-980 \mathrm{~cm}^{-1}$ respectively. These bands appear slightly in the higher region $\left(+10\right.$ to $\left.20 \mathrm{~cm}^{-1}\right)$ than the parent aluminium(III) thiolates. Moreover, $v\left(\mathbf{C}_{-}-\mathbf{C}\right)$ and $v\left(\mathbf{C}_{--}-\mathrm{N}\right)$ modes due to ligand molecules ${ }^{17}$ are also present in the adducts around 1600-1590 $\mathrm{cm}^{-1}$, which otherwise are absent (except thiophenol) in the parent thiolates thereby confirming that the ligand molecule has been added. These coordination compounds are also insoluble in commonly used organic solvents and have high melting point indicating their polymeric nature like their parent thiolates.

Current efficiencies of all these systems have also been determined and are quite high (in the range of 0.76 to 0.97 gram equivalents per Faraday) thereby showing that the reaction leading to the formation of aluminium(III) thiolates and their coordination compounds are the predominant reactions of these systems.

\section{Conclusion}

The present studies thus reveal that the electrochemical method for the synthesis of aluminium(III) thiolates and their coordination complexes is a single step process and offers a versatile approach for the commercial preparation of these compounds. 


\section{Acknowledgement}

We are highly thankful to UGC (New Delhi) for the financial support in the form of Major Research Project.

\section{References}

1. Maan C K and Bains K K, Electrochemical Reactions in Non-Aqueous System, Marcel- Dekker Inc, N.Y., 1970.

2. Youichi Tsuchiya and Hisashi Fujihara, Electrochem., 2002 ,70, 584.

3. Davies J A, Eagles C T, Farrar D G and Burckel P, Inorg Chem Acta, 2000, 300-302, 465-652.

4. Singh Suman, Jain D V S and Singla M L, Analy Methods, 2013, 5(4), 1024-1032; DOI:10.1039/C2AY26201K

5. Venkata S M and Sharma N P, Pharma Bioworld, 2003, 1(2), 101.

6. Kellogg R M and Hoff R P, J Chem Soc Perkin Trans., 1996, 1, 1651.

7. Banait J S, Deol S K and Singh Baljit, Synth React Inorg Met-Org Chem., 1990, 20(10), 1331-1342.

8. Banait J S and Singh Baljit, Indian J Chem., 1991, 30A, 895.

9. Banait J S, Singh Baljit and Kaur Harpreet , Indian J Chem., 2007, 46A, 266-268.

10. Singh Baljit and Kaur Harpreet, J Chem., 2012, 9(1), 381-388.

11. Banait J S, Singh Baljit and Rala Sarbjit, J Indian Chem Soc., 2009, 86, 416.

12. Banait J S, Singh Baljit and Kaur Harpreet, J Indian Chem Soc., 2011, 88, 641.

13. Singh Baljit and Bala Kanchan, Kaur Gurpreet, Singh Simrat, Chem Sci Trans., 2013, 2(1), 222-226.

14. Fangfei Liu, Suquin Liu, Qiuju Feng, Shuxin Zhuang, Jinbao Zhang and Peng Bu, Int J Electrochem Sci., 2012, 7, 4381-4387.

15. Vogel's, Text book of Quantitative Chemical Analysis, Longman group UK, Ltd., 1989.

16. Banait J S, Singh Baljit and Rala Sarbjit, J Indian Chem Soc., 2007, 84, 135.

17. Dyre J R, Applications of Absorption Spectroscopy of Organic Compounds, Prentice Hall of India Pvt. Ltd., New Delhi, 1978.

18. Banait J S, Singh Baljit and Kaur Harpreet, J Indian Chem Soc., 2005, 82, 555.

19. Mangani S, Carloni P and Orioli P, Coord Chem Rev., 1992, 120(1), 309-324.

20. Bradley D C, Mehrotra R C and Gaur D P, Metal Alkoxides., Academic Press, New York, 1978. 